\title{
Görsel Peyzaj Kalite Değerlendirmesi: Kıyıköy Örneği
}

\author{
Tuğba KIPER $\quad$ Aslı KORKUT Tuğba ÜSTÜN TOPAL \\ Namık KemalÜniv.,Güzel Sanatlar, Mimarlık ve Tasarım Fak. Peyzaj Mimarlığı Böl., Tekirdağ \\ $\bowtie$ : tkiper@nku.edu.tr
}

Geliş (Received): 07.10.2016

Kabul (Accepted): 02.01.2017

\begin{abstract}
ÖZET: Bu çalışmada; özellikle görsel kalite algısının çevre tercihlerinde etkili olduğu öngörüsü ile, Kıyıköy'ün görsel peyzaj açısından çekicilik gösteren alanlarının tanımlanması hedeflenmiştir. Bu amaçla görsel peyzaj analizi ile; uzman ve gözlemci grubundan oluşan katılımcıların Kıyıköy'e ilişkin 12 adet fotoğrafi, 6 ana (doğallık, uyum, okunabilirlik, arazi şekli, rekreasyonel değer, manzara güzelliği) ve 22 alt başlıktan oluşan parametreler açısından çeşitli ölçeklerde değerlendirmeleri sağlanmıştır. Değerlendirmeler sonucunda; her iki grubun tercihlerinde benzerlikler olduğu görülmüştür. Bununla birlikte doğal bitki örtüsü ile deniz ve kıyısının uyumlu bir bütünlük oluşturduğu, algılanabilir, topografik çeşitliliğin gözlemlendiği, doğal ve yapay elemanların uyumlu ve düzenli bir şekilde bulunduğu görüntüler görsel açıdan olumlu olarak değerlendirilmiştir.
\end{abstract}

Anahtar kelimeler: Görsel algı, görsel peyzaj analizi, estetik, Kıyıöy.

\section{Visual Landscape Quality Assessment: Kıyıköy Example}

\begin{abstract}
In this study; especially with the foresight to be effective in environmental preferences of visual quality perception, it has been aimed to identify the areas showing attractiveness in terms of visual landscape. For this purpose, participants, consisting of experts and observer group evaluated 12 photographs regarding to Kıyı̈öy in various scales and parameters consisting of 6 main titles (naturality, harmony, perceptibility, shape of land, recreational value, landscape beauty) and 22 sub-titles with the visual landscape analysis. According to the results of evaluations; similarities were found for both groups' preferences. At the same time, images which form a harmonious integrity with natural vegetation, sea and its coast, were perceptible and topographic diversity, compatible and organized natural and artificial elements were evaluated favorably.
\end{abstract}

Keywords: Visual perception, visual landscape analysis, aesthetics, Kiyıköy.

\section{GíRiş}

Peyzaj, bir görüş alanı içerisine giren doğal ve kültürel varlıklara ait ekolojik, sosyo-ekonomik ve estetik değerlerin oluşturduğu bir bütündür (Özhanc1 ve ark., 2013). Beza (2010)'ya göre peyzaj; manzarayı kapsayan, manzarayı tasvir eden ya da görsel açıdan yerini tutan estetik deneyimdir (Özhanc1 ve Yılmaz, 2013). Forman (1995) peyzajı, geniş alanlarda benzer formlarla tekrarlanan arazi kullanımları ya da yerel ekosistemlerin karışımı olan bir mozaik olarak tanımlamıştır. Avrupa Peyzaj Sözleşmesi (2000)'ne göre peyzaj, insanlar tarafindan algılandığı şekliyle, karakteri doğal ve/veya insani unsurların eyleminin ve etkileşiminin sonucu olan bir alandır (https://www.tbmm.gov.tr/...) Söz konusu tanımlamalar, peyzajın; doğal ve kültürel elemanların karşılıklı olarak etkileştiği bir sistemler bütünü olduğunu göstermektedir.

Görsel alg1, duyular yoluyla çevreden bilgi edinme eylemi olup (Göler, 2009); görsellik, güzellik, hoşnutluk, estetik gibi kavramlarla ifade edilmektedir (Daniel, 2001). Dolayısıyla görsel algı, beğeni ve rekreasyonel tercihlerde etkili olup, alan kullanım planlaması ve kaynak yönetimi karar verme-strateji geliştirme ve yönetim aşamaları gibi pek çok çalışmada bir değişken olarak yer almaktadır (Clay ve Daniel, 2000; Tüfekçioğlu Kuğu, 2008; Çağlayan Kaptanoğlu, 2008; Uzun ve Müderrisoğlu, 2011; Caf, 2014). Öyle ki, Peyzaj Mimarlığı mesleği yetki alanlarının tanımlandığı "Türk Mühendis ve Mimar Odaları Birliği Peyzaj Mimarları
Odası Serbest Peyzaj Mimarlık Müşavirlik Hizmetleri Uygulama, Meslekî Denetim, Büroların Tescili ve Asgarî Ücret Yönetmeliği"nde, "görsel peyzaj analizi ile yaşama ilişkin görsel peyzaj ve estetik kalitesinin değerlendirilmesi" ibaresi ile, peyzajın görsel niteliğine dikkat çekilmektedir (http://www. peyzaj.org.tr/mevzuat/...). Bununla birlikte birçok araştırmada görsel kalite algısının, mekan tercihlerinin belirlenmesinde etkili olduğu saptanmıştır (Dramstad ve ark., 2006; Kaplan ve ark., 2006; Polat ve Acar, 2010; Uzun ve Müderrisoğlu, 2011; Polat ve ark., 2012; Çelik, 2013; Kiper ve Cengiz, 2016). Dolayısıyla bir görünümün görsel açıdan üstün olması; o alanın tercih edilme sıklığını artıracak, alan kullanım planlaması ile karar verme-strateji geliştirme ve yönetim aşamalarında yol gösterici olacaktır. Bununla birlikte Özgüç (1999) planlama aşamasında, yörenin görsel niteliğinin saptanarak analizinin yapılmasının, görsel kaynakların korunması için en doğru yöntem olduğundan bahsetmiştir (Özgeriş ve Karahan, 2015). Clay ve Daniel (2000)'e göre görsel nitelik, turizm potansiyeli taşıyan alanlarda turistik/rekreasyonel deneyimin kalitesini etkileyebilmektedir.

Bu çalışmada, Kırklareli İli Vize İlçesi'nde doğal ve kültürel kimliğiyle yerel ve bölgesel düzeyde önem taşıyan Kıyıköy Beldesi kıyı alanlarının görsel peyzaj analizi yardımıyla tanımlanması amaçlanmıştır. Kıyıköy; Türkiye Turizm Stratejisi Eylem Planı'nda ve Kırklareli İl Çevre Düzen Plan'ında (Anonim, 2007; Anonim, 2011) 
"Ekoturizm kenti" olarak geliştirilmesi hedeflenmiş, aynı zamanda Türkiye'nin en büyük metropolü olan İstanbul'un etki alanında yer alan bir yerleşim birimidir. Kıyıköy ve çevresi; zengin kıyıları, kayın, meşe ve 1hlamur ormanları, doğal bitki örtüsü, doğal ve kentsel sit alanları, mağaraları (Bostanlıktarla, Kovantaşı, Kurudere, Domuzdere, Yenesu), geleneksel yerleşim dokusu, sivil mimari örnekleri, mutfak kültürü gibi

\section{MATERYAL ve METOT}

\section{Materyal}

Bu çalışmanın ana materyalini Kırklareli İli Vize İlçesi Kıyıköy beldesi kıyı bandı oluşturmaktadır. Çalışma alanı $41^{\circ} 63^{\prime} 48.18^{\prime \prime} \mathrm{K}$ ve $28^{\circ} 09^{\prime} 64.04^{\prime \prime D}$ koordinatları arasında bulunmakta olup, Trakya Bölgesi'nin Karadeniz kıyı kuşağında yer almaktadır niteliklerinden dolayı önemli bir turizm potansiyeline sahiptir. Kıyıköy örneğinde gerçekleştirilen bu çalışma ile, mekan tercihlerinde uzman bir grup ve gözlemci grubu yardımıyla i) Görsel bakımdan yüksek nitelikli peyzajları tanımlamak, ii) Mekan tercihleri ile parametreler arasındaki ilişkileri belirlemek ve $i i i)$ uzman ve gözlemci gruplar arasındaki tercih farklarını irdelemek amaçlanmıştır.

(Şekil 1). Kırklareli il merkezine $88 \mathrm{~km}$, ilçe merkezine $36 \mathrm{~km}$ uzaklıktaki beldenin yüzölçümü $155 \mathrm{~km}^{2}$, dir.

Araştırma alanına ait 12 adet fotoğraf, görsel peyzaj değerlendirmesine ait önceki çalışmalar, uzman ve gözlemcilerin görüşlerinin belirlenmesinde yararlanılan anket formları, bu çalışmada değerlendirilen diğer materyallerdir. Anket sonuçlarının değerlendirilmesi ve istatistiki analizlerde SPSS yazılımı kullanılmıştır.

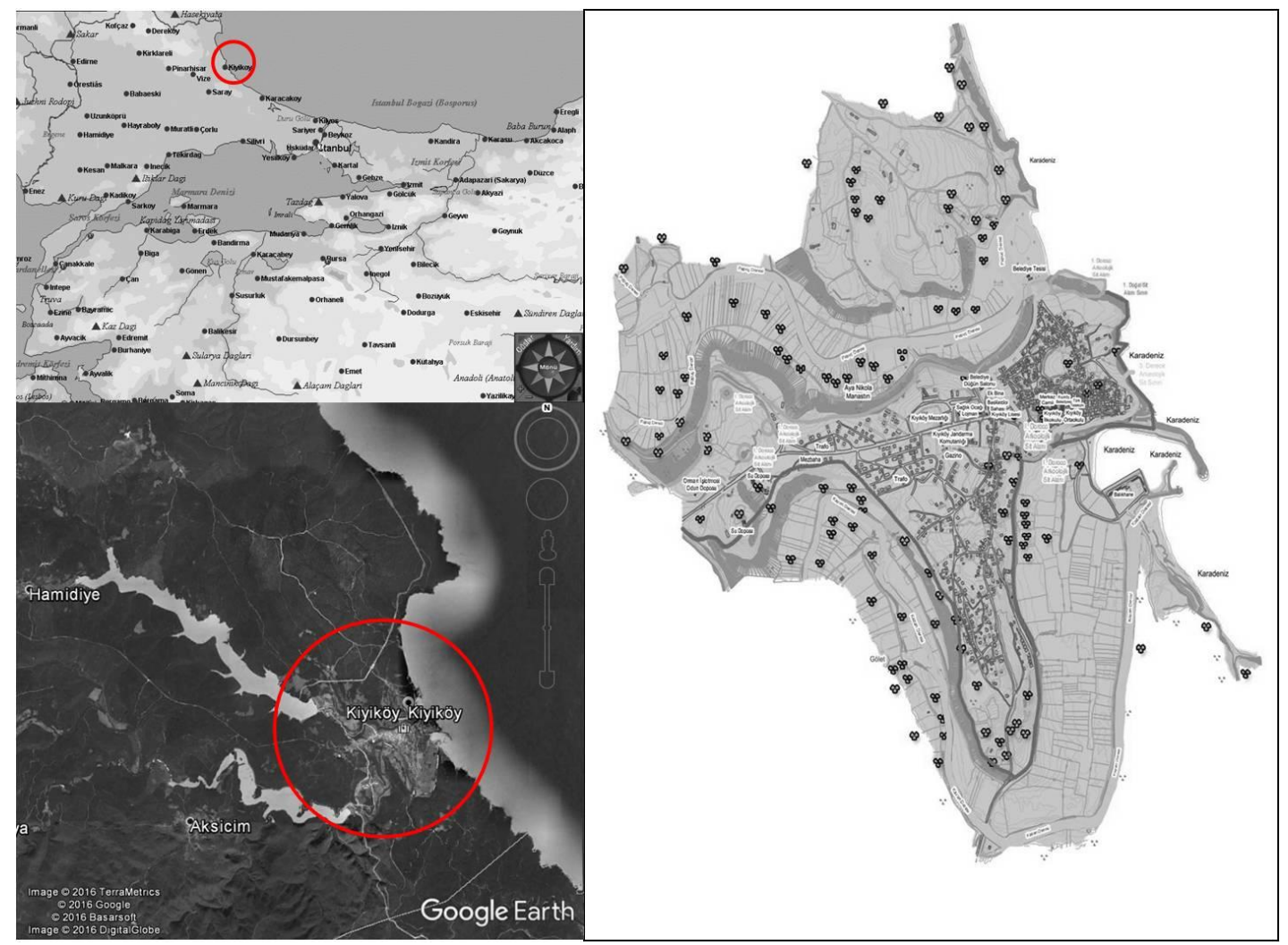

Şekil 1. Araştırma alanı coğrafi konumu

\section{Metot}

Çalışmanın hedefi, görsel peyzaj analizi yardımıyla Kıyıköy'de ekoturizm planlamasına katkıda bulunacak manzara özelliklerinin tanımlanmasıdır. Kıyıköy’e ait görüntüler kullanılarak uzman ve gözlemci değerlendirmeleri ile görsel kalite analizi yapılmıştır. Çalışmanın yöntemi yedi temel aşamadan meydana gelmiştir.

- Amaç ve kapsamın belirlenmesi (Ekoturizm gelişimi için ayrılmış ve henüz yapılaşmamış bir kırsal alan için "görsel peyzaj analizi” ile panoramik açıdan çekicilik gösteren alanların tanımlanmasını sağlamak),
-Alan ve konu hakkında literatür araştırmasının yapılması (Yöntemde kullanılan parametrelerin belirlenmesine yönelik görsel peyzaj kalitesi ile ilgili yapılmış çalışmalar irdelenmiştir (Çizelge 1). $\mathrm{Bu}$ çalışmalar görsel kalite analizinin peyzaj planlama ve tasarım çalışmaları için kullanıcı tercih ve beğenilerinin belirlenmesi ve elde edilen bilgilerin yapılacak planlamalarda göz önünde bulundurulmasının önemini ortaya koyması açısından önemlidir),

- Görsel etki değerini tanımlayan ölçütlerin belirlenmesi (Çizelge 2), (Clay ve Daniel, 2000; Arriaza ve ark. 2004, Çakc1, 2007; Tüfekçioğlu Kuğu, 2008; Özhanc1 ve Yılmaz, 2011; Çelik, 2013), 
Çizelge 1. Yöntemde kullanılan parametrelerin belirlenmesinde yararlanılan çalışmalar

\begin{tabular}{|c|c|c|}
\hline Yazarlar & Anket Grubu & Parametreler \\
\hline Çakc1 (2007) & $\begin{array}{l}\text { Uzman } \\
\text { Kullanici }\end{array}$ & $\begin{array}{l}\text { Düzenli- karmaşık, açık- kapalı, bakımlı- bakımsız, basit- çeşitli, doğal elemanlar } \\
\text { baskın- yapısal elemanlar baskın }\end{array}$ \\
\hline Kiroğlu (2007) & Kullanıci & $\begin{array}{l}\text { Su (su akışı, su kaynağı tipi, su oranı), bitki örtüsü (vejetasyonla kaplı alan oranı, } \\
\text { vejetasyon tipi), topografya (topografya tipi), kültürel elemanlar (insan yapımı pozitif } \\
\text { elemanların varlığı/yer ve tipik evler, insan yapımı negatif elemanların varlığı /yol, } \\
\text { endüstri, enerji hatları vb., insan yapımı elemanların oranı), renk (renklerin sayısı, renk } \\
\text { uyumu), kompozisyon (baskın görünüş, odak görüntü), tekstür, doğallık (doğallık } \\
\text { derecesi), algılanabilirlik (kitle-boşluk oranı), gökyüzü (gökyüzü oranı) }\end{array}$ \\
\hline $\begin{array}{l}\text { Tüfekçioğlu Kuğu } \\
\text { (2008) }\end{array}$ & Yazar & $\begin{array}{l}\text { Tutarlılık (doğal çevre ve arazi kullanımının uyumu, suyun varlığı ve mekansal konumu, } \\
\text { objelerin birbiriyle uyumu ve bütünlüğ̈̈, renklerin ve dokuların tekrarı), okunabilirlik } \\
\text { (planın algılanabilirliği, açı yönlenmesi, keskin sınırlar, ayırt edici ögelerin mekana } \\
\text { dağılımı, yol hiyerarşisi), komplekslilik (farklı objelerin varlığı, çeşitliliği ve zenginliği, } \\
\text { düzlük - eğimlilik, şekil ve boyut çeşitliliği,), geçicilik mevsimsel değişikliğe uğrayan } \\
\text { bitki örtüsü, faunanın mekana etkisi, periyodik tarım aktivitelerinin varlığı, mevsimsel } \\
\text { değişiklikten etkilenen su alanı, özgün hava koşulları, tasvir edilebilirlik (manzara } \\
\text { noktalarının, olağanüstü, eşsiz ögelerin, nirengi noktalarının, tarihi unsurların ve } \\
\text { dokuların, su elemanlarının varlı̆ğ ve hareketli su alanı), sahip çıkma (terk edilmemiş } \\
\text { alan bakımlı binalar ve lineer objeler (duvar, yol, çit vb.), atıkların bulunmaması, drenaj, } \\
\text { ekin veren, bitki bulunan yerlerde ıslak alanların varlığı, yabani otların bulunmaması), } \\
\text { tarihsellik (tarihi kültürel unsurların, lineer tarihi ögelerin varlığı ve çeşitleri, tarihi } \\
\text { zaman katmanlarının görünürlüğü, tarihi devamlllı̆ğ olan alanın varlığ1, geleneksel } \\
\text { arazi kullanımı ve dokusunun varlığı), doğallık (el değmemiş bitki örtüsü, fraktal boyut } \\
\text { su varlığı, doğäl ögelerin bulunması, geçici bitki örtüsü), görsel ölçek (her açıdan } \\
\text { görünürlük, görülebilir alan büyüklüğü, görüntü derinliği, açıklı derecesi, objelerin } \\
\text { görüntüyü engellememesi); mekan duygusu (mekan kimliğinin algılanması, mekan } \\
\text { kültürüne ait objelerin bulunması, topografya, bitkisel ve yapısal ögelerin uyumu, } \\
\text { bakımlı, temiz alanların varlığı, mekana ait ögelerarası ilişkinin güçlü olması) }\end{array}$ \\
\hline $\begin{array}{l}\text { Irmak ve Yilmaz } \\
(2010)\end{array}$ & Kullanicı & $\begin{array}{l}\text { Bitkisel çeşitlilik, doğal manzara etkisi, orman ve çayır-mera varlığı, etkili su ögesi, dağ } \\
\text { manzaras, tarihi ve arkeolojik değerler, kırsal yerleşim ögelerine sahip olma, etkili } \\
\text { jeomorfolojik ögelerin varlığı, renk etkisi/canlılık, orijinallik/özgünlük, heyecan ve } \\
\text { güven vericilik, ulaş1labilirlik ve en fazla ilgi çeken bölge }\end{array}$ \\
\hline $\begin{array}{l}\text { Özhanc1 ve Y1lmaz } \\
\text { (2011) }\end{array}$ & Kullanıcı & Doğallık, çeşitlilik, uyum, açıklık, gizem, perspektif, güven, düzen, rekreasyon değeri \\
\hline Dinçer (2011) & $\begin{array}{l}\text { Uzman, } \\
\text { Kullanic1 }\end{array}$ & Ritim, tekrar, denge, oran, vurgu, armoni, beğeni \\
\hline Elinç (2011) & Kullanıcı & $\begin{array}{l}\text { Manzara, uyum, doğallık, bakım, açıklık, düzen, hareket, heyecan verici, güven, } \\
\text { manzara güzelliği }\end{array}$ \\
\hline Çelik (2013) & $\begin{array}{l}\text { Uzman } \\
\text { Kullanic1 } \\
\end{array}$ & Doğallık, çeşitlilik, açıklık, karmaşıklık, gizem, güven, düzen, manzara güzelliği \\
\hline Gültürk (2013) & $\begin{array}{l}\text { Uzman } \\
\text { Kullanıc1 } \\
\end{array}$ & $\begin{array}{l}\text { Doğal-yapay eleman baskın, uyumlu- uyumsuz, bakımlı -bakımsız, açık- kapalı, } \\
\text { düzenli- düzensiz, güvenli -güvensiz, manzara güzelliği olumsuz }\end{array}$ \\
\hline $\begin{array}{l}\text { Çelik ve Açıksöz } \\
(2014)\end{array}$ & $\begin{array}{l}\text { Uzman } \\
\text { Kullanıc1 } \\
\end{array}$ & $\begin{array}{l}\text { Morfolojik yapı, bitki örtüsü, su varlığı, renk, algılanabilirlik, kültürel elemanlar ve } \\
\text { etkileşim alanı }\end{array}$ \\
\hline Caf (2014) & Kullanic1 & $\begin{array}{l}\text { Doğallık, çeşitlilik, gizem, manzara güzelliği, uyum, ilginçlik, güven, canlılık, heyecan } \\
\text { verme ve özgünlük }\end{array}$ \\
\hline $\begin{array}{l}\text { Benliay ve ark. } \\
(2015)\end{array}$ & $\begin{array}{l}\text { Uzman } \\
\text { Kullanıc1 } \\
\end{array}$ & $\begin{array}{l}\text { Doğallık, çeşitlilik, uyum, açıklık, gizem, perspektif, arazi şekli, manzara ve rekreasyon } \\
\text { değeri }\end{array}$ \\
\hline $\begin{array}{l}\text { Düzgüneş ve } \\
\text { Demirel (2015) }\end{array}$ & Uzman & Canlılık, peyzaj çeşitliliği, doğallık, uyum/harmoni, etkileyicilik ve gizemlilik \\
\hline $\begin{array}{l}\text { Kiper ve Cengiz } \\
(2016)\end{array}$ & Kullanıc1 & $\begin{array}{l}\text { Uyum, okunabilirlik, etkili su ögesi varlığı, açıklık, düzen, güvenilirlik, orijinallik, } \\
\text { manzara güzelliği ve tarihi doku }\end{array}$ \\
\hline
\end{tabular}


Çizelge 2. Araştırmada kullanılan parametreler

\begin{tabular}{|c|c|c|c|c|}
\hline \multirow{22}{*}{ 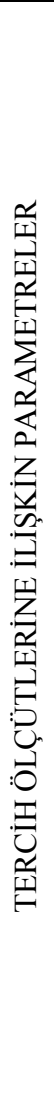 } & \multirow{3}{*}{ 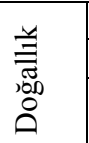 } & Doğal bitki örtüsünün varlığı & \multirow{4}{*}{ 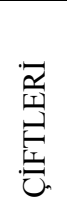 } & \multirow{3}{*}{ Doğal olmayan-doğal } \\
\hline & & Su varlığ1 & & \\
\hline & & Diğer doğal ögelerin varlığı (toprak, kayaç, arazi tipi vb.) & & \\
\hline & \multirow{3}{*}{$\underset{\Xi}{\Xi}$} & Arazi kullanımının doğal unsurlarla uyumu & & \multirow{3}{*}{ Uyumsuz-uyumlu } \\
\hline & & $\begin{array}{l}\text { Topografya, bitkisel ögeler ve yapısal ögelerin birbiriyle } \\
\text { uyumu }\end{array}$ & $\underset{\mathbb{1}}{\mathrm{E}}$ & \\
\hline & & Alanın mevcut ögeleriyle kimlik (karakter) kazanması & $\bar{n}$ & \\
\hline & \multirow{6}{*}{ 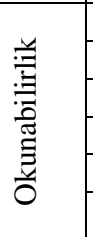 } & Peyzajın algılanabilirliği & $\overrightarrow{\omega_{n}}$ & \multirow{6}{*}{ Kapalılık hissi-açıklık hissi } \\
\hline & & Algıya açık yönlenme & 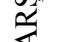 & \\
\hline & & Algıya kapalılık (sınırlılık) & 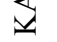 & \\
\hline & & Ayırt edici ögelerin varlığı & Z & \\
\hline & & Alanda bulunan özgün ögelerin varlı̆̆ 1 & $\frac{v}{n}$ & \\
\hline & & Bakımlı temiz alan varlığı & $\exists$ & \\
\hline & \multirow{2}{*}{ 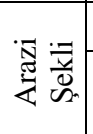 } & Arazi topografyasının değişkenliği (düzlük - eğimlilik) & $\frac{1}{2}$ & \multirow{6}{*}{ Sade-çeşitli } \\
\hline & & Arazide şekilsel çeşitlilik (deniz, dağ, ova, vadi vb.) & 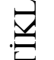 & \\
\hline & \multirow{4}{*}{ 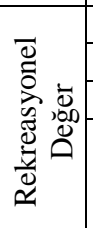 } & Eşsiz ögelerin varlı̆̆1 & \multirow{8}{*}{ 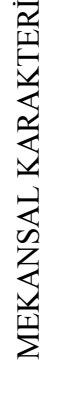 } & \\
\hline & & Odak noktası oluşturan unsurların varlığ1 & & \\
\hline & & Kültürel unsurların varlığ1 & & \\
\hline & & $\begin{array}{l}\text { Turistik alt ve üst yapının varlığı (yol, motel, otel, restoran } \\
\text { vb.) }\end{array}$ & & \\
\hline & \multirow{4}{*}{ 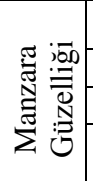 } & Görüntünün açıklı̆̆ı(seçilebilirlik) & & \multirow{4}{*}{ Algilanmayan-algilanabilir } \\
\hline & & Görülebilen alanın büyüklüğü & & \\
\hline & & Görüntünün derinliği & & \\
\hline & & Görüntünün netliği (engelleyen unsurların olmaması) & & \\
\hline
\end{tabular}

-Değerlendirmede kullanılacak fotoğrafların çekilmesi ve uygun olanlarının seçimi (2015 yllı ilkbahar döneminde gerçekleştirilen arazi çalışmaları ile araştırma alanında farklı yükseltilerden olmak üzere, panoramik bakı noktalarından çekilen fotoğraflardan en uygun 12 adeti görsel analiz çalışmasında kullanılmıştır (Çizelge 3). Çalışma kapsamında çok sayıda fotoğraf çekilmiş ve yöntemde kullanılan 12 adet fotoğrafin seçiminde; kullanıcılar tarafindan görülme olasıllı̆ $\breve{~ e n ~}$ yüksek olan manzaraların varlığı esas alınarak panoramik noktaların varlığı, doğal ve kültürel peyzaj ögelerinin yer alması ile görüntü kalitesi etken olmuştur.

-Uzman ve gözlemci gruplara fotoğrafların (powerpoint sunu şeklinde) gösterilerek anket uygulanması (Namık Kemal Üniversitesi Peyzaj Mimarlığı, Mimarlık ve Resim Bölümleri öğretim üyelerinden meydana gelen 22 kişi uzman grup olarak belirlenmiş, aynı bölümlerin 3. ve 4. sınıf öğrencilerinin meydana getirdiği 98 kişi ise gözlemci grup olmuştur. Her iki gruba da aynı değerlendirme formu sunulmuş ve alana ilişkin 12 adet fotoğrafi belirlenen puanlama aralığında değerlendirmeleri istenmiştir. Değerlendirmelerde, her bir görüntüye ilişkin ana ve alt parametreler Likert ölçeğinde 1, 2, 3, 4, 5 aralığında (5 en yüksek, 4 yüksek, 3 orta, 2 düşük ve 1 en düşük), mekansal karakteristikleri içeren karşıt sıfat çiftleri ise -2,$1,0,+1,+2$ aralığında ( -2 en düşük, +2 en yüksek, 0 nötr) olmak üzere puanlandırılmıştır),

- Bulguların istatistiksel analizi (Anketlerin değerlendirilmesinde 'SPSS 23' istatistik paket programı kullanılarak, aritmetik ortalama, minimum ve maksimum değerler ile standart hata ve standart sapma gibi tanımlayıcı istatistiksel analizler çerçevesinde karşlaştırma yapılmıştır.)

- Sonuç ve önerilerin geliştirilmesi (Tanımlayıcı istatistikler yolu ile elde edilen araştırma bulgularına dayanarak uzman ve gözlemci grubunun tercihleri ile parametreler arasında ilişki kurulmuştur. Analizler çerçevesinde çıkan sonuçlar her iki grup için karşılaştrılarak en çok ve en az tercih edilen parametreler ve görüntüler tespit edilmiştir. Uzman ve gözlemci grubuna aynı parametrelerle değerlendirme yaptırılmasının nedeni; görüntülerin görsel peyzaj özellikleri ile mekansal tercihler arasinda farklılık olup olmadığını tespit etmektir. Kiracıoğlu (2007)'nun da bahsettiği gibi, görsel peyzaj kalitesinin belirlendiği çalışmalarda, uzmanlar ve/ veya gözlemcilerin beğenilerine yönelik tercihlerinin ortak bir paydada toplanması temel hedeftir) 
Çizelge 3. Değerlendirmede kullanılan görüntüler ve çekim noktaları

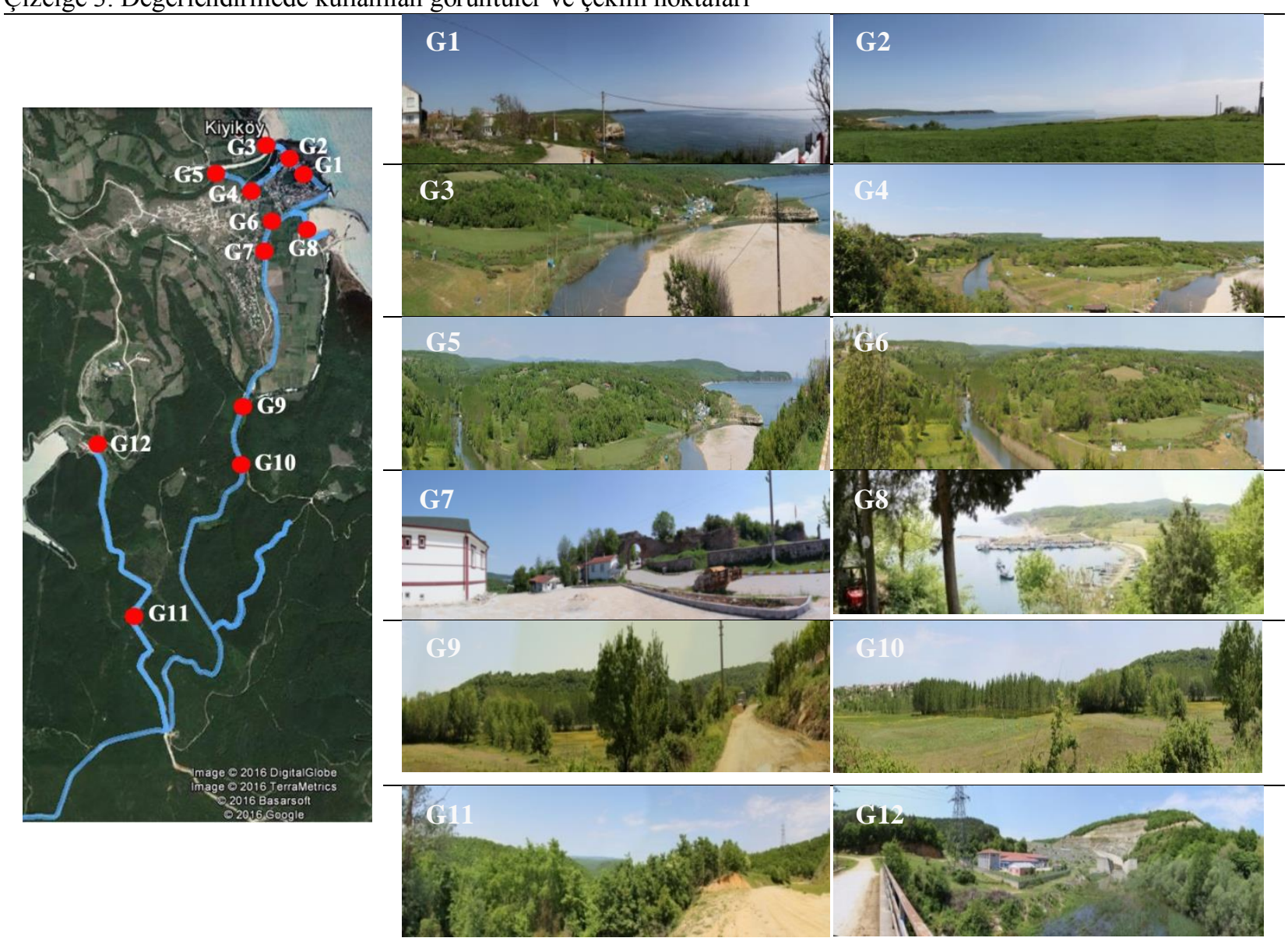

1 Nolu Görünüm:Kıyıköy sahil yolu, sağda Kıyıköy sahili, solda yapraklı bitki dokusu

2 Nolu Görünüm: Kıyıköy sahiline bakış

3 Nolu Görünüm: Pabuçdere ile denizin birleşim noktası, sağda yoğun bitki dokusu, solda Kıyıköy kumsalı

4 Nolu Görünüm: Kıyıköy sahilinden Pabuçdereye uzaktan bakış,

5 Nolu Görünüm: Pabuçdere'nin deniz ve yeşil doku ile kesişim noktası, sağda sahil ve deniz, solda yoğun bitki dokusu

6 Nolu Görünüm: Yoğun yeşil doku ve tarım alanlarının Pabuçdere ile birleşim noktası

7 Nolu Görünüm: Kıyıköy çıkış yolu, sağda yapraklı ağaç dokusu, solda yapı kitlesi

8 Nolu Görünüm: Kıyıköy Limanına bakış, sağda orman dokusu, solda deniz

9 Nolu Görünüm: Kıyıköy'den Saray ilçesine giden orman yolu, solda yoğun orman dokusu

10 Nolu Görünüm: Kıyıköy'den Saray ilçesine giden orman yolunun solunda yer alan yeşil doku

11 Nolu Görünüm: Kıyıköy'ü Tekirdağ'a bağlayan orman yolu

12 Nolu Görünüm: Kazandere baraj yolu, sağda Kazandere solda köprü

\section{BULGULAR}

Uzman anketine göre katılımcılar; Kıyıköy Limanı'nın yer aldığı 8 numaralı görüntüyü on parametre, Pabuçdere'nin denizle birleştiği alanda yer alan 2, 3 ve 6 numaralı görüntüleri ise dört parametre açısından olumlu olarak değerlendirmişlerdir (Çizelge 4). Gözlemci anketinde ise 8 numaralı görüntü on altı parametre, 6 numaralı görüntü sekiz ve 2 numaralı görüntü ise iki parametre açısından olumlu olarak belirlenmiştir (Çizelge 5).

Uzman ve gözlemci grubu anket sonuçları doğrultusunda en çok tercih edilen alt parametrelerin aldıkları aritmetik ortalama değerleri Çizelge 6'da verilmiştir. 
Çizelge 4. Uzman grubunun anket değerlendirmelerine göre parametre bazında en yüksek puan alan görüntüler

\begin{tabular}{|c|c|c|c|c|c|c|}
\hline \multicolumn{3}{|c|}{ Ana ve Alt Parametreler } & No & \multicolumn{2}{|c|}{ Ana ve Alt Parametreler } & No \\
\hline \multirow{7}{*}{\multicolumn{2}{|c|}{ 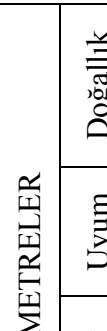 }} & Doğal bitki örtüsünün varlığı & 6 & \multirow{22}{*}{ 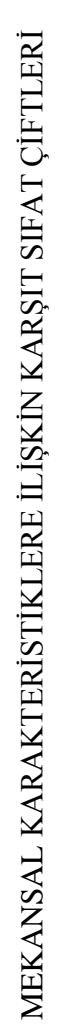 } & \multirow{3}{*}{ Doğal olmayan-doğal } & \multirow{3}{*}{6,11} \\
\hline & & Su varlı̆̆ & 3 & & & \\
\hline & & Diğer ögelerin varlı̆̆ı (toprak, kayaç, arazi tipi vb.) & 3 & & & \\
\hline & & Arazi kullanımının doğal unsurlarla uyumu & 3 & & \multirow{3}{*}{ Uyumsuz- uyumlu } & \multirow{3}{*}{8} \\
\hline & & Topografya, bitkisel ögeler ve yapısal ögelerin birbiriyle uyumu & 6 & & & \\
\hline & & Alanın mevcut ögeleriyle kimlik (karakter) kazanması & 8 & & & \\
\hline & & Peyzajın algılanabilirliği & 8 & & \multirow{6}{*}{$\begin{array}{l}\text { Kapall1ık hissi- } \\
\text { açiklık hissi }\end{array}$} & \multirow{6}{*}{2} \\
\hline 㲾 & \multirow{5}{*}{ 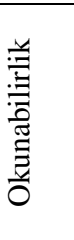 } & Algiya açık yönlenme & 8 & & & \\
\hline$t_{2}$ & & Algiya kapalılık (sinırlılık) & 7 & & & \\
\hline $\mathrm{z}^{2}$ & & Ayırt edici ögelerin varlığı & 8 & & & \\
\hline 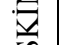 & & Alanda bulunan özgün ögelerin varlığı & 3,8 & & & \\
\hline ה. & & Bakımlı temiz alan varlığı & 2 & & & \\
\hline & \multirow{2}{*}{ 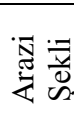 } & Arazi topografyasının değişkenliği (düzlük - eğimlilik) & 8 & & \multirow{6}{*}{ Sade-çeşitli } & \multirow{6}{*}{8} \\
\hline & & Arazide şekilsel çeşitlilik (deniz, dağ, ova, vadi vb.) & 8 & & & \\
\hline & \multirow{4}{*}{ 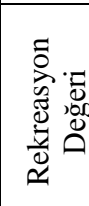 } & Eşsiz ögelerin varlığı & 8 & & & \\
\hline ב-ב & & Odak noktası oluşturan unsurların varlığı & 8 & & & \\
\hline$: 0$ & & Kültürel unsurların varlığı & 7 & & & \\
\hline & & Turistik alt ve üst yapının varlığı (yol, otel, restoran vb.) & 7 & & & \\
\hline & \multirow{4}{*}{ 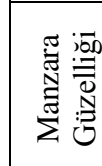 } & Görüntünün açıklı̆̆ (seçilebilirlik) & 6 & & \multirow{4}{*}{$\begin{array}{l}\text { Algilanmayan- } \\
\text { algllanabilir }\end{array}$} & \multirow{4}{*}{5} \\
\hline & & Görülebilen alanın büyüklüğü & 2 & & & \\
\hline & & Görüntünün derinliği & 5 & & & \\
\hline & & Görüntünün netliği (engelleyen unsurların olmaması) & 2 & & & \\
\hline
\end{tabular}

Çizelge 5. Gözlemci grubunun anket değerlendirmelerine göre parametre bazında en yüksek puan alan görüntüler

\begin{tabular}{|c|c|c|c|c|c|c|}
\hline \multicolumn{3}{|c|}{ Ana ve Alt Parametreler } & No & \multicolumn{2}{|c|}{ Ana ve Alt Parametreler } & No \\
\hline \multirow{7}{*}{ 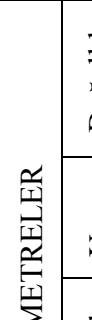 } & \multirow{3}{*}{ 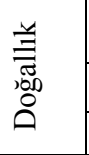 } & Doğal bitki örtüsünün varlığı & 6 & \multirow{2}{*}{ 茎 } & \multirow{3}{*}{ Doğal olmayan-doğal } & \multirow{3}{*}{6} \\
\hline & & Su varlığ 1 & 8 & & & \\
\hline & & Diğer ögelerin varlığı (toprak, kayaç, arazi tipi vb.) & 3 & 臬 & & \\
\hline & \multirow{3}{*}{ 志 } & Arazi kullanımının doğal unsurlarla uyumu & 8 & $\mathrm{G}$ & \multirow{3}{*}{ Uyumsuz- uyumlu } & \multirow{3}{*}{8} \\
\hline & & Topografya, bitkisel ögeler ve yapısal ögelerin birbiriyle uyumu & 6,8 & 死 & & \\
\hline & & Alanın mevcut ögeleriyle kimlik (karakter) kazanması & 6,8 & $\overline{\mathrm{n}}$ & & \\
\hline & \multirow{6}{*}{ 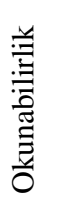 } & Peyzajin algılanabilirliği & 8 & $=$ & \multirow{6}{*}{$\begin{array}{l}\text { Kapal1lık hissi- } \\
\text { açıklı hissi }\end{array}$} & \multirow{6}{*}{2,6} \\
\hline \multirow{5}{*}{ 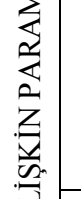 } & & Algıya açık yönlenme & 8 & $\frac{2}{4}$ & & \\
\hline & & Algiya kapalılık (sinirlılı) & 7 & $\frac{v}{7}$ & & \\
\hline & & Ayırt edici ögelerin varlı̆ı̆ & 8 & 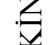 & & \\
\hline & & Alanda bulunan özgün ögelerin varlığ 1 & 8 & . & & \\
\hline & & Bakımlı temiz alan varlı̆ı & 8 & $\exists$ & & \\
\hline \multirow{3}{*}{ 量 } & \multirow{2}{*}{$\begin{array}{ll}\pi & = \\
0\end{array}$} & Arazi topografyasının değişkenliği (düzlük - eğimlilik) & 8 & \multirow{2}{*}{ 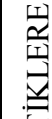 } & \multirow{6}{*}{ Sade-çeşitli } & \multirow{6}{*}{8} \\
\hline & & Arazide şekilsel çeşitlilik (deniz, dağ, ova, vadi vb.) & 8 & & & \\
\hline & \multirow{4}{*}{ 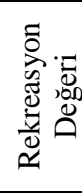 } & Eşsiz ögelerin varlığı & 8 & \multirow{8}{*}{ 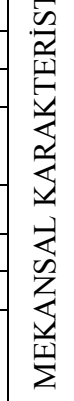 } & & \\
\hline : & & Odak noktası oluşturan unsurların varlığı & 8 & & & \\
\hline . & & Kültürel unsurların varlığı & 8 & & & \\
\hline : & & Turistik alt ve üst yapının varlı̆̆ı (yol, otel, restoran vb.) & 7 & & & \\
\hline$\frac{\mathrm{q}}{\mathrm{y}}$ & \multirow{4}{*}{ 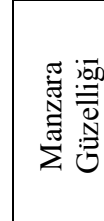 } & Görüntünün açıklığı (seçilebilirlik) & 6 & & \multirow{4}{*}{$\begin{array}{l}\text { Algilanmayan- } \\
\text { algilanabilir }\end{array}$} & \multirow{4}{*}{6,8} \\
\hline & & Görülebilen alanın büyüklüğü & 6 & & & \\
\hline & & Görüntünün derinliği & 6 & & & \\
\hline & & Görüntünün netliği (engelleyen unsurların olmaması) & 2 & & & \\
\hline
\end{tabular}


Çizelge 6. En yüksek puana sahip parametrelerin aldıkları aritmetik ortalama değerleri

\begin{tabular}{|c|c|c|c|}
\hline No & Parametreler & Uzman & Gözlemci \\
\hline \multirow[t]{2}{*}{1} & Su varlı̆̆1 & 4,1739 & 4,3367 \\
\hline & Doğal Olmayan-doğal & 3,7826 & 3,8776 \\
\hline \multirow[t]{3}{*}{2} & Su varlığı & & 4,3776 \\
\hline & Görüntünün netliği & 4,4348 & \\
\hline & Doğal olmayan-doğal & 4,5217 & 4,7347 \\
\hline \multirow[t]{2}{*}{3} & Doğal bitki örtüsünün varlığı & 4,6087 & 4,3265 \\
\hline & Doğal olmayan-doğal & 4,5217 & 4,3061 \\
\hline \multirow[t]{2}{*}{4} & Doğal bitki örtüsünün varlığı & 4,6957 & 4,6224 \\
\hline & Doğal olmayan-doğal & 4,4783 & 4,6224 \\
\hline \multirow[t]{4}{*}{5} & Doğal bitki örtüsünün varlığı & 4,5217 & 4,5612 \\
\hline & Görülebilen alanın büyüklüğü & 4,5217 & \\
\hline & Doğal olmayan-doğal & & 4,3571 \\
\hline & Algilanmayan-algılanabilir & 4,2609 & \\
\hline \multirow[t]{2}{*}{6} & Doğal bitki örtüsünün varlığı & 4,8261 & 4,7755 \\
\hline & Doğal olmayan-doğal & 4,6087 & 4,8163 \\
\hline \multirow[t]{2}{*}{7} & Görüntünün açıklığı & 3,6087 & 3,4082 \\
\hline & Algilanmayan-algılanabilir & 3,6087 & 3,4082 \\
\hline \multirow[t]{2}{*}{8} & Doğal bitki örtüsünün varlığı & 4,6087 & 4,5612 \\
\hline & Doğal olmayan-doğal & 4,3913 & 4,4796 \\
\hline \multirow[t]{2}{*}{9} & Doğal bitki örtüsünün varlığ1 & 4,6522 & 4,6531 \\
\hline & Doğal olmayan-doğal & 4,4348 & 4,5816 \\
\hline \multirow[t]{2}{*}{10} & Doğal bitki örtüsünün varlığı & 4,4348 & 4,6633 \\
\hline & Doğal olmayan-doğal & 4,4348 & 4,6837 \\
\hline \multirow[t]{2}{*}{11} & Doğal bitki örtüsünün varlığı & 4,4348 & 4,4592 \\
\hline & Doğal olmayan-doğal & 4,6087 & 4,5816 \\
\hline \multirow[t]{3}{*}{12} & Doğal bitki örtüsünün varlığ1 & & 3,9082 \\
\hline & Arazi topografyasının değişkenliği & 4,1304 & \\
\hline & Algilanmayan-algilanabilir & 3,9130 & 3,6939 \\
\hline
\end{tabular}

Uzman ve gözlemci grubu anket sonuçları çerçevesinde ana parametrelere göre belirlenen en yüksek ve en düşük puanlı görüntüler ve aritmetik ortalama değerleri Çizelge 7'de, yine her iki grubun en çok tercih ettiği alt parametreler ise Çizelge $8^{\prime}$ de verilmiştir. Çizelge $8^{\prime}$ e göre her iki grubun da ortak tercihleri doğallık için doğal bitki örtüsünün varlığı, arazi şekli için arazide şekilsel çeşitlilik, rekreasyonel değer için odak noktası oluşturan unsurların varlığı, manzara güzelliği için görülebilen alanın büyüklüğü, mekansal karakteristikler için ise doğal olmayan-doğal alt parametreleri doğrultusunda olmuştur.

Çizelge 7. Ana parametrelere göre en yüksek ve en düşük puanlı görüntüler ve aritmetik ortalama değerleri

\begin{tabular}{|l|l|l|l|l|}
\hline \multicolumn{1}{|c|}{ Parametreler } & \multicolumn{2}{c|}{ Uzman } & \multicolumn{2}{c|}{ Gözlemci } \\
\hline \multirow{2}{*}{ Doğallık } & En az & $1,942 \mathrm{G} 7$ & En az & $1,829 \mathrm{G} 7$ \\
\cline { 2 - 5 } & En çok & $4,507 \mathrm{G} 3$ & En çok & $4,282 \mathrm{G} 8$ \\
\hline \multirow{2}{*}{ Uyum } & En az & $2,304 \mathrm{G} 7$ & En az & $2,384 \mathrm{G} 7$ \\
\cline { 2 - 6 } & En çok & $4,203 \mathrm{G} 8$ & En çok & $4,051 \mathrm{G} 8$ \\
\hline \multirow{2}{*}{ Okunabilirlik } & En az & $2,609 \mathrm{G} 2$ & En az & $2,801 \mathrm{G} 7$ \\
\cline { 2 - 6 } & En çok & $3,601 \mathrm{G} 8$ & En çok & $3,342 \mathrm{G} 6$ \\
\hline \multirow{2}{*}{ Arazi şekli } & En az & $2,674 \mathrm{G} 7$ & En az & $2,408 \mathrm{G} 7$ \\
\cline { 2 - 6 } & En çok & $4,152 \mathrm{G} 8$ & En çok & $3,847 \mathrm{G} 8$ \\
\hline \multirow{2}{*}{ Rekreasyonel değer } & En az & $1,989 \mathrm{G} 10$ & En az & $1,106 \mathrm{G} 10$ \\
\cline { 2 - 6 } & En çok & $3,336 \mathrm{G} 8$ & En çok & $3,194 \mathrm{G} 8$ \\
\hline \multirow{2}{*}{ Manzara güzelliği } & En az & $3,217 \mathrm{G} 9$ & En az & $2,982 \mathrm{G} 7$ \\
\cline { 2 - 6 } & En çok & $4,261 \mathrm{G} 2$ & En çok & $4,048 \mathrm{G} 2$ \\
\hline \multirow{2}{*}{$\begin{array}{l}\text { Mekansal } \\
\text { karakteristikler }\end{array}$} & En az & $3,096 \mathrm{G} 7$ & En az & $2,906 \mathrm{G} 7$ \\
\cline { 2 - 6 } & En çok & $4,148 \mathrm{G} 8$ & En çok & $4,210 \mathrm{G} 6$ \\
\hline
\end{tabular}


Çizelge 8. En yüksek puan alan alt parametreler

\begin{tabular}{|c|c|c|c|}
\hline \multicolumn{2}{|l|}{ Parametreler } & Uzman & Gözlemci \\
\hline \multirow[t]{3}{*}{ Doğallık } & Doğal bitki örtüsünün varlığ1 & & \\
\hline & Su varlığı & & \\
\hline & Diğer doğal ögelerin varlığı (toprak, kayaç, arazi tipi vb.) & & \\
\hline \multirow[t]{3}{*}{ Uyum } & Arazi kullanımının doğal unsurlarla uyumu & & \\
\hline & Topografya, bitkisel ögeler ve yapısal ögelerin birbirleriyle uyumu & & \\
\hline & Alanın mevcut ögeleriyle kimlik kazanması & & \\
\hline \multirow[t]{6}{*}{ Okunabilirlik } & Peyzajın algılanabilirliği & & \\
\hline & Algıya açık yönlenme & & \\
\hline & Algıya kapalılık (sınırlılık) & & \\
\hline & Ayırt edici ögelerin varlığı & & \\
\hline & Alanda bulunan özgün ögelerin varlığı & & \\
\hline & Bakımlı temiz alan varlığı & & \\
\hline \multirow[t]{2}{*}{ Arazi şekli } & Arazi topografyasının değişkenliği (düzlük-eğimlilik) & & \\
\hline & Arazide şekilsel çeşitlilik (deniz, dağ, ova, vadi vb.) & & \\
\hline \multirow[t]{4}{*}{ Rekreasyonel değer } & Eşsiz ögelerin varlığı & & \\
\hline & Odak noktası oluşturan unsurların varlığ1 & & \\
\hline & Kültürel unsurların varlığı & & \\
\hline & $\begin{array}{l}\text { Turistik alt ve üst yapının varlığ } \\
\text { (yol, motel, otel, restoran vb.) }\end{array}$ & & \\
\hline \multirow[t]{4}{*}{ Manzara güzelliği } & Görüntünün açıklığı (seçilebilirliği) & & \\
\hline & Görülebilen alanın büyüklüğü & & \\
\hline & Görüntünün derinliği & & \\
\hline & Görüntünün netliği (engelleyen unsurların olmaması & & \\
\hline \multirow{5}{*}{$\begin{array}{l}\text { Mekansal } \\
\text { karakteristikler }\end{array}$} & Doğal olmayan-doğal & & \\
\hline & Sade-çeşitli & & \\
\hline & Uyumsuz-uyumlu & & \\
\hline & Alg1lanmayan-algilanabilir & & \\
\hline & Kapalılık hissi-açıklık hissi & & \\
\hline
\end{tabular}

Uzman ve gözlemci grubunun görüntülere ilişkin değerlendirme sonuçları Çizelge 9'da verilmiştir. Buna göre; her iki grup tarafindan; doğallık, uyum, arazi şekli ve mekansal karakteristikleri içeren karşıt sıfat çiftleri açısından en az tercih edilen görüntü Kıyıköy'ün çıkışında yer alan yapısal ögelerin baskın olduğu 7 numaralı fotoğraf olurken, rekreasyonel değer açısından en az tercih edilen görüntü tarım ve orman dokusunun birlikte yer aldığ 10 numaralı fotoğraf olmuştur. Okunabilirlik ve manzara güzelliği parametrelerinde her iki grubun tercihleri farklı olmuştur. Okunabilirlik için uzman grubu tarafindan en az tercih edilen görüntü Kıyıköy'ün Karadeniz'le buluştuğu 2 numaralı fotoğraf olurken, gözlemci grubunda 7 numaralı görüntü en düşük oranda tercih edilmiş̧ir. Manzara güzelliği için uzman grubu tarafindan en az tercih edilen Kazandere Barajina giden yol boyundaki 9 numaralı görüntü olurken, gözlemci grubunda 7 numaralı fotoğraf olmuştur.
Kıyıköy Limanı (uyum, arazi şekli ve rekreasyonel değer parametreleri açısından) ve Kıyıköy'ün Karadeniz bölümü (manzara güzelliği parametresi açısından) her iki grup tarafindan en yüksek oranda tercih edilmiştir. Bununla birlikte doğallık, okunabilirlik ve mekansal karakteristikleri içeren karşıı sıfat çiftlerinde her iki grubun tercihleri farklı olmuştur. Keza doğallık için uzman grubu tarafindan en fazla tercih edilen görüntü 3 numaralı fotoğraf olurken, gözlemci grubunda 8 numaralı görüntü en fazla oranda tercih edilmiştir. Okunabilirlik ve mekansal karakteristiklerde uzman grubu tarafindan en fazla tercih edilen görüntü 8 olurken, gözlemci grubunda 6 numaralı fotoğraf olmuştur (Çizelge 9).

Her iki gruba uygulanan anket değerlendirmeleri çerçevesinde elde edilen sonuçlar, uzman ve gözlemci durumuna göre kısmen değişse de ortalama değerler ele alındığında tercihlerde benzer bir eğilim olduğu söylenebilmektedir. 
Çizelge 9. Görüntülere ilişkin değerlendirme sonuçları

\begin{tabular}{|c|c|c|c|c|c|c|c|c|c|c|c|c|c|c|c|}
\hline \multirow[b]{2}{*}{ 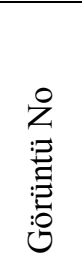 } & \multirow[b]{2}{*}{ 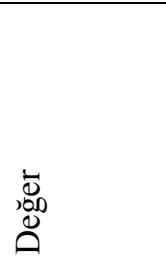 } & \multicolumn{7}{|c|}{ Uzman grubu } & \multicolumn{7}{|c|}{ Gözlemci grubu } \\
\hline & & 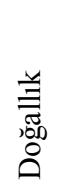 & 声 & 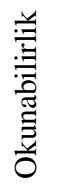 & 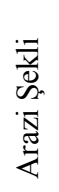 & 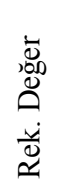 & 密 & 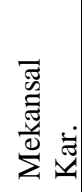 & 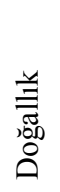 & 声 & 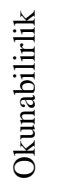 & 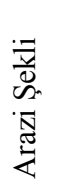 & 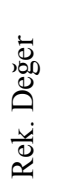 & 窵语 & 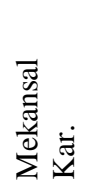 \\
\hline \multirow{2}{*}{ G1 } & En düşük & & & & & & & & & & & & & & \\
\hline & En yüksek & & & & & & & & & & & & & & \\
\hline \multirow{2}{*}{$\mathrm{G} 2$} & En düşük & & & & & & & & & & & & & & \\
\hline & En yüksek & & & & & & & & & & & & & & \\
\hline \multirow{2}{*}{ G3 } & En düşük & & & & & & & & & & & & & & \\
\hline & En yüksek & & & & & & & & & & & & & & \\
\hline \multirow{2}{*}{ G4 } & En düşük & & & & & & & & & & & & & & \\
\hline & En yüksek & & & & & & & & & & & & & & \\
\hline \multirow{2}{*}{ G5 } & En düşük & & & & & & & & & & & & & & \\
\hline & En yüksek & & & & & & & & & & & & & & \\
\hline \multirow{2}{*}{ G6 } & En düşük & & & & & & & & & & & & & & \\
\hline & En yüksek & & & & & & & & & & & & & & \\
\hline \multirow{2}{*}{ G7 } & En düşük & & & & & & & & & & & & & & \\
\hline & En yüksek & & & & & & & & & & & & & & \\
\hline \multirow{2}{*}{ G8 } & En düşük & & & & & & & & & & & & & & \\
\hline & En yüksek & & & & & & & & & & & & & & \\
\hline \multirow{2}{*}{ G9 } & En düşük & & & & & & & & & & & & & & \\
\hline & En yüksek & & & & & & & & & & & & & & \\
\hline \multirow{2}{*}{ G10 } & En düşük & & & & & & & & & & & & & & \\
\hline & En yüksek & & & & & & & & & & & & & & \\
\hline \multirow{2}{*}{ G11 } & En düşük & & & & & & & & & & & & & & \\
\hline & En yüksek & & & & & & & & & & & & & & \\
\hline \multirow{2}{*}{ G12 } & En düşük & & & & & & & & & & & & & & \\
\hline & En yüksek & & & & & & & & & & & & & & \\
\hline
\end{tabular}

\section{TARTIŞMA ve SONUÇ}

Bayer (1990)'in belirttiği gibi, turizm ve çevre arasında güçlü bir ilişki olup, çevresel, doğal ve kültürel özelliklerin her biri turizm için cezbedici bir değerdir (Özhancı ve Yılmaz, 2013). Bununla birlikte Clay ve Daniel (2000) turizm veya rekreasyonel bağlamda doğal çevrenin başlıca bileşenini, görsel veya manzara kalitesi olarak belirtmektedir. Bu kapsamda, Kıyıköy, ekoturizm etkinlikleri için önemli bir panoramik çekicilik sunmaktadır. Bu doğrultuda, Kıyıköy özelinde mekansal tercihlerde uzman bir grup ve gözlemci grubu yardımıyla görsel bakımdan yüksek nitelikli peyzajlar tanımlanmış, mekan tercihleri ile parametreler arasındaki ilişkiler belirlenmiş̧tir. Yapılan görsel peyzaj analizi sonucunda, öncelikle her bir ana ve alt parametre için uzman ve gözlemci tarafindan en yüksek ve en düşük puan alan görüntüler incelenerek çıkan sonuçlar benzer çalışmalarla desteklenmiştir. Daha sonra da bütün bu değerlendirmeler sonucunda en az ve en çok tercih edilen görüntüler çerçevesinde Kıyıköy'ün görsel peyzaj kalite değerlendirmesi yapılmıştır (Çizelge 10).

Her bir ana parametre için uzman ve gözlemci tarafindan yapılan değerlendirmelere göre;
Doğallık parametresi için; her iki grup yapay elemanların baskın olduğu Kıyıköy'ün çıkışında yer alan yol boyuna en az puanı vermiştir. Bununla birlikte en yüksek puan alan fotoğraf uzman ve gözlemci grubu için farklılık göstermiş, uzman grubu en yüksek puanı Pabuçdere'nin denizle birleştiği alandaki 3 numaralı fotoğrafa verirken, gözlemci grubu ise 8 numaralı fotoğrafa vermiştir. Nitekim; Schroeder (1982), Tips ve Savasidara (1986), Kaplan ve Kaplan (1989), Nasar (1992), Parsons (1991), Kaplan ve ark.(1998), Acar ve ark. (2006), Çakcı ve Çelem (2009) ve Yılmaz ve ark. (2013)'nın yapmış oldukları çalışmalarda da doğallık parametresinin görsel peyzajlarda etkili olduğuna ilişkin benzer sonuçlar ortaya çıkmıştır. Alt parametrelerde ise doğal bitki örtüsünün varlığı en çok tercih edilen parametre olmuştur. Bu sonuç ise McAndrew ve ark. (1998), Daniel (2001) ve Arriaza ve ark. (2004), Özhanc1 ve Yılmaz (2013), Çelik (2013), Caf (2014)'ın çalışmaları ile benzerlik göstermektedir. $\mathrm{Bu}$ çalışmalarda; katılımcıların tercihlerini bitkisel materyalin etkin olduğu alanlardan yana kullandıkları ortaya çıkmıştır. 
Çizelge 10. Araştırma alanına ilişkin görsel peyzaj değerlendirme sonucu

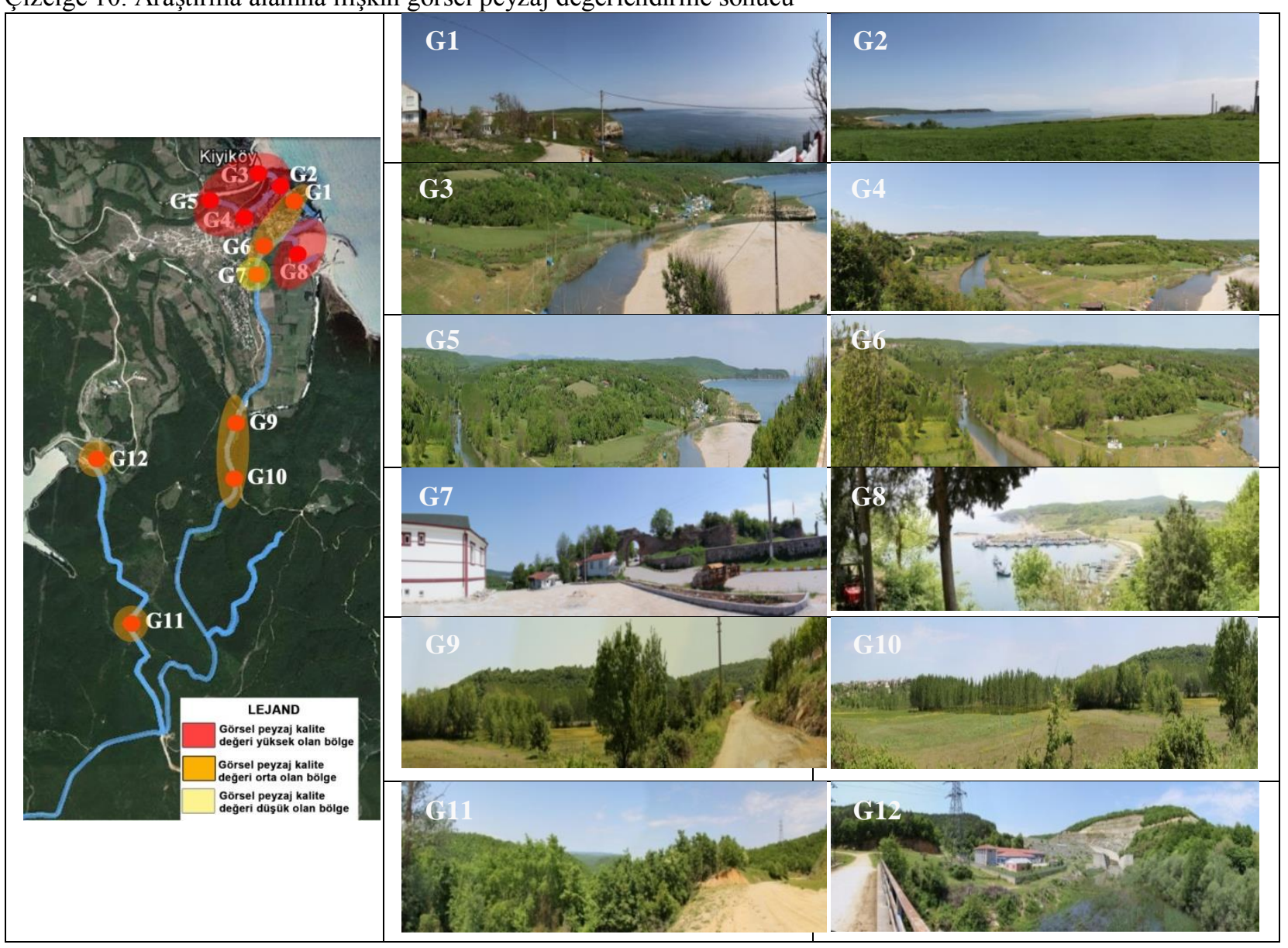

Uyum parametresi için; her iki grup 7 numaralı fotoğrafa en düşük, 8 numaralı fotoğrafa ise en yüksek puanı vermiştir. $\mathrm{Bu}$ sonuç, Yılmaz ve ark. (2013), Özgeriş ve Karahan (2015)'ın çalışması ile paralellik göstermektedir. Bu çalışmalarda uyum parametresinin, estetik tasarımın temelini oluşturan faktörlerden biri olduğu ve yüksek olmasının ortalama görsel kalite puanını da olumlu yönde etkilediği belirtilmiştir.

Okunabilirlik parametresi için uzman ve gözlemci grubu tercihleri farklılık göstermiştir. Uzman grubu 2 numaralı fotoğrafa en düşük puanı verirken, gözlemci grubu ise 7 numaralı fotoğrafa en düşük puanı vermiştir. En yüksek puanı alan görüntü uzman grup için 8 olurken, gözlemci grubu için 6 numaralı fotoğraf olmuştur. $\mathrm{Bu}$ kapsamda, Bell (1999), Tüfekçioğlu Kuğu (2008) ve Çakcı ve Çelem (2009)'in yapmış oldukları çalışmalar bu sonuçlar ile benzerlik göstermektedir.

Arazi şekli parametresi için, her iki grup 7 numaralı fotoğrafa en düşük, 8 numaralı fotoğrafa ise en yüksek puanı vermiştir. Özhancı ve ark. (2012)'nın çalışmasında görsel peyzaj açısından hareketli peyzajlar homojen ve düze yakın alanlara göre daha fazla dikkat çekmektedir.

Rekreasyonel değer parametresi için, her iki grup 10 numaralı fotoğrafa en düşük, 8 numaralı fotoğrafa ise en yüksek puanı vermiştir. Irmak ve Yılmaz (2010), Özhancı ve Yılmaz (2011), Özgeriş ve Karahan (2015)'ın yaptıkları çalışmalarda görsel peyzaj kalitesinin rekreasyonel tercihlerde etkili olduğu ortaya çıkmıştır.

Manzara güzelliği parametresi için; en düşük puan alan fotoğraf uzman ve gözlemci grubu için farklılık göstermiş olup, uzman grubu en düşük puanı 9 numaralı fotoğrafa verirken, gözlemci grubu ise 7 numaralı fotoğrafa vermiştir. Bununla birlikte, her iki grup 2 numaralı fotoğrafa en yüksek puanı vermiştir. Bu sonuç, Clay ve Daniel (2000), Benliay ve ark. (2015), Özhancı ve Yılmaz (2013), Elinç (2011)'in yapmış oldukları çalışmaların sonuçlarını desteklemektedir. Mekansal karakteristikleri içeren karşıt sıfat çiftleri grubunda ise her iki grup 7 numaralı fotoğrafa en düşük puanı vermiştir. Bununla birlikte, en yüksek puan alan fotoğraf uzman ve gözlemci grubu için farklılık göstermiş; uzman grubu en yüksek puanı 8 numaralı fotoğrafa verirken, gözlemci grubu ise 6 numaralı fotoğrafa vermiştir.

Genel olarak değerlendirildiğinde, yeşil ve kıyının uyumlu bir bütünlük oluşturduğu, algllanabilir, topografik çeşitliliğin gözlemlendiği, doğal ve yapay elemanların uyumlu ve düzenli bir şekilde bulunduğu görüntüler (Kıyıköy limanı, Pabuçdere, Karadeniz sahili gibi Karadeniz'e bağlanan Kıyıköy kıyılarının olduğu bölge) görsel açıdan olumlu olarak değerlendirilirken, yeşil alan varlı̆̆ının az olduğu buna karşın yapay elemanların baskın olduğu, bütüncül ve algllanabilir olmayan görüntüler (Kazandere baraj yolu, Kıyıköy çıkış 
yolu gibi Kıyıköy'ün iç kısımlarında yer alan yerleşim alanlarının görüldüğü ve vista noktalarının azaldığ bölge) ise görsel açıdan olumsuz olarak değerlendirilmiştir (Çizelge 10 ).

Elde edilen sonuçlar doğallık, uyum, bakım ve okunabilirlik parametrelerinin görsel kaliteyi etkilediğini göstermektedir. Aynı zamanda bu parametreler ekoturizme yönelik tercihleri de etkileyici unsurlar olarak nitelendirilebilmektedir. Bu doğrultuda, peyzaj planlama ve tasarım çalışmalarında görsel peyzaj kalite değerlendirmelerinin yapılması oldukça önemli bir altyapı sağlayacaktır. Örneğin ekoturizme yönelik olarak tematik rotaların belirlenmesinde, foto safari yapılacak alanların ve vista noktalarının saptanmasında yol gösterici olacaktır.

$\mathrm{Bu}$ çalışma ile, turizm ve rekreasyonel alan kullanımın üretilmesinde uzman görüşlerini ve kullanıcı talep ve beklentilerini ortaya koyan stratejiler geliştirilmesi mümkün olabilecektir. Peyzaj planlama ve tasarımı çalışmalarında, görsel bakımdan yüksek niteliklere ve çekiciliğe sahip alanların ekoturizm faaliyetleri içerisinde değerlendirilmesi ve bu alanların rekabet koşullarının desteklenmesi sağlanabilecektir.

\section{TEŞEKKÜR}

Bu çalışma NKUBAP.00.18.AR.14.10 No'lu Namık Kemal Üniversitesi Bilimsel Araştırma Projesi ile desteklenmiştir.

\section{KAYNAKLAR}

Acar C, Kurdoğlu BÇ, Kurdoğlu O, Acar H 2006. Public Preferences for Visual Quality and Management in the Kaçkar Mountains National Park (Turkey). International Journal of Sustainabe Development and World Ecology, 13: 499-512.

Anonim 2007. Türkiye Turizm Stratejisi 2023 Eylem Planı. Kültür ve Turizm Bakanlığı, s.60, Ankara,

Anonim 2011. Kırklareli İl Çevre Düzen Planı, 2011. Kırklareli İl Özel İdaresi, İstanbul Büyükşehir Belediyesi, Trakya Kalkınma Birliği, İstanbul Büyükşehir Belediyesi Metropoliten Planlama ve Kentsel Tasarım Merkezi, s.79.

Arriaza M, Canas-Ortega JF, Canas-Madueno JA, RuizAviles P 2004. Assessing the Visual Quality of Rural Landscapes. Lanscapeand Urban Planning, 69:115125.

Beza BB 2010. The aesthetic value of a mountain landscape: A study of the Mt. Everest Trek. Landscape and Urban Planning, 97:306-317.

Bell S 1999. Landscape Pattern, Perception and Process. E\&FN Spon, London.

Benliay A, Soydan O, Kayku M 2015. AspendosSillyon- Perge Bisiklet Güzergahı Örneğinde Peyzaj Görsel Kalitesi ve Peyzaj Özelliklerinin Değerlendirilmesi. Artium, 3(1):48-64.

Caf A 2014. Bingöl-Erzurum Karayolu Güzergâhının Görsel Kalite Analizi. Atatürk Üniversitesi Fen Bilimleri Enstitüsü Peyzaj Mimarlığı Ana Bilim Dalı, Yüksek Lisans Tezi, 100s.
Clay GR, Daniel TC 2000. Scenic Landscape Assesssment: The Effects of Land Management Jurisdiction on Public Perception of Scenic Beauty. Landscape and Urban Planning, 49: 1-13.

Çağlayan Kaptanoğlu AY 2008. Peyzajın Görsel Analizinde Grafik Düşünme Süreci ve Soyutlama. İstanbul Üniversitesi Orman Fakültesi Dergisi, 58(2): 25-38.

Çakcı I 2007. Peyzaj Planlama Çalışmalarında Görsel Peyzaj Değerlendirmesine Yönelik Bir Yöntem Araştırması, Ankara Üniversitesi Fen Bilimleri Enstitüsü Peyzaj Mimarlığı Anabilim Dalı, Doktora Tezi, Ankara.

Çakcı I, Çelem H 2009. Kent Parklarında Görsel Peyzaj Algısının Değerlendirilmesi. Ankara Üniversitesi Ziraat Fakültesi Tarım Bilimleri Dergisi, 15(1): 8895.

Çelik D, Açıssöz S 2014. Planlama Sürecine Görsel Peyzaj Analizi ile Etik Yaklaşım: Amasra Örneği. 2nd International Symposium on Environment And Morality, 24-26 October, pp: 320-331, Adiyaman.

Çelik M 2013. Kent Parklarının Görsel Peyzaj Algısının Denizli İli Örneğinde İrdelenmesi. Süleyman Demirel Üniversitesi Peyzaj Mimarlığı Anabilim Dalı, Yüksek Lisans Tezi, Isparta.

Daniel TC 2001. Whiter Scenic Beauty? Visual Landscape Quality Assessment in the 21st Century. Landscape Urban and Planning, 54: 267-281

Dinçer AA 2011. Görsel Peyzaj Kalitesinin "Biçimsel Estetik Değerlendirme Yaklaşımı” İle İrdelenmesi Üzerine Bir Araştırma. Ankara Üniversitesi Fen Bilimleri Enstitüsü Peyzaj Mimarlığı Anabilim Dalı, Yüksek Lisans Tezi, Ankara.

Dramstad WE, Tveit MS, Fjellstad WJ, Fry GLA 2006. Relationships Between Visual Landscape Preferences and Map-Based Indicators of Landscape Structure. Landscape and Urban Planning, 78: 465-474.

Düzgüneş E, Demirel Ö 2015. Milli Parklarda Doğal ve Kültürel Kaynak Değerlerinin Görsel Peyzaj Kalite Yönünden Değerlendirilmesi. İnönü Üniversitesi Sanat ve Tasarım Dergisi, 5 (12): 13-23.

Elinç H 2011. Görsel Kalite Değerlendirmesi Yöntemi ile Antalya İli Alanya ilçesindeki Abdurrahman Alaeddinoğlu ve Alanya Belediye Başkanları Kent Parklarının İrdelenmesi. Selçuk Üniversitesi Fen Bilimleri Enstitüsü Peyzaj Mimarlığı Anabilim Dalı, Yüksek Lisans Tezi, Konya.

Forman RTT 1995. Land Mosaics - The Ecology of Landscape and Regions. Cambridge University Press, 632 p, Cambridge, UK.

Göler S 2009. Biçim, Renk, Malzeme, Doku ve Işı̆̆ın Mekân Algısına Etkisi. Mimar Sinan G.S.Ü. Fen BilimleriEnstitüsü, Yüksek Lisans Tezi, İstanbul.

Gültürk P 2013. Tekirdağ Kent Merkezi Kıyı Şeridinin Görsel Peyzaj Kalitesi Yönünden Değerlendirilmesi. Namık Kemal Üniversitesi Fen Bilimleri Enstitüsü Peyzaj Mimarlığı Anabilim Dalı, Yüksek Lisans Tezi, Tekirdağ.

http://www.peyzaj.org.tr/mevzuat/mevzuat_detay.php? kod=145. (Erişim tarihi: 27.06.2014) 
https://www.tbmm.gov.tr/kanunlar/k4881.html (Erişim tarihi: 02.01.2017)

Irmak MA, Yılmaz H 2010. Farklı Peyzaj Karakter Alanlarına Göre Doğal ve Kültürel Kaynak Değerlerinin Görsel Analizi: Erzurum Örneği. GOÜ Ziraat Fakültesi Dergisi, 27(2): 45-55.

Kaplan A, Taşkın T, Önenç A 2006. Assessing the Visual Quality of Ruraland Urban-Fringed Landscapes Surrounding Livestock Farms. Biosystems Engin, 95 (3):437-448.

Kaplan R, Kaplan S, Ryan RL 1998. With People in Mind. Island Press, 239 p.,USA.

Kaplan R, Kaplan S 1989. The Experience of Nature: A Psychological Perspective. Cambridge University, Cambridge U.K.

Kıroğlu E 2007. Erzurum Kenti ve Yakın Çevresindeki Bazı Rekreas-yon Alanlarının Görsel Peyzaj Kalite-si Yönünden Değerlendirilmesi. Atatürk Üniversitesi Fen Bilimleri Enstitüsü, Yüksek Lisans Tezi, Erzurum.

Kiper T, Cengiz T 2016. İstanbul İli Beşiktaş İlçesi Kıyı Bandı Örneğinde Görsel Peyzajların Tanımlanması. 1st International Scientific Researches Congress Humanity and Social Sciences (Ibad-2016), May 19 22, 2016 Madrid, Spain, 1330-1342.

Kiracıoğlu Ö 2007. Orman Alanlarındaki Görsel Kalitenin Tahmini: Çeşmealtı Ormanları Örneği. Süleyman Demirel Fen Bilimleri Enstitüsü, Yüksek Lisans Tezi, Isparta.

McAndrew FT, Turner S, Fiedeldey AC, Sharma Y 1998. A Cross-Cultural Ranking of the Pleasantness of Visual and Non-visual Features of Outdoor Environments. Davis, California.

Nasar JL 1992. Visual Preferences in Urban Street Scenes: A Cross Cultural Comparison Between Japan and the United States. Environmental Aethetics: Theory, Researchand Applications (Ed. Nasar, J.L.), Cambridge University Press, New York.

Özgeriș M, Karahan F 2015. Rekreasyonel Tesislerde Görsel Kalite Değerlendirmesi Üzerine Bir Araştırma: Tortum Ve Uzundere (Erzurum) Örneği. Artvin Çoruh Üniversitesi Orman Fakültesi Dergisi, 16(1): 40-49.

Özgüç IM 1999. TEM Hadımköy-Kınalı Arası Peyzaj Planlaması Üzerinde Görsel Araştırmalar. İÜ Orman Fakültesi Dergisi, A Serisi, 49 (2), 115-132.
Özhancı E, Yılmaz H 2011. Rekreasyon Alanlarının Görsel Peyzaj Kalitesi Yönünden Değerlendirilmesi; Erzurum Örneği. Iğdır Üni. Fen Bilimleri Enst. Dergisi, 1(2): 67-76.

Özhancı E, Yılmaz H 2013. Değişik Peyzaj Karakterleri Barındıran Dağların, Foto Safari Amaçlı Görsel Peyzaj Analizi. Atatürk Üniv. Ziraat Fak. Derg., 44 (1): 83-89.

Özhanc1 E, Irmak MA, Y1lmaz H 2012. Ekolojik Koridorlar Kapsaminda Erzurum-Uzundere Güzergahı Vadi Peyzajı Tiplerinin Ortaya Konması. KSÜ Doğa Bilimleri Dergisi, Özel Sayı, 45-54.

Özhancı E, Yılmaz H, Tekin H 2013. Ödüllü Peyzaj Fotoğraflarına Analitik Bir Yaklaşım. Humanitas Uluslararası Sosyal Bilimler Dergisi, 2:151-168

Parsons R 1991. The Potential Influences of Environmental Perception on Human Held. J.Environ. Psychol, 11: 1-23.

Polat Z, Acar C 2010. Peyzajda Neden Görsel Kalite Analizi Yaparız? Artvin Çoruh Üniversitesi Orman Fakültesi Dergisi, 10 (2): 19- 29.

Polat AT, Güngör S, Adryaman S 2012. Konya Kenti Yakın Çevresindeki Kentsel Rekreasyon Alanlarının Görsel Kalitesi İle Kullanıcıların Demografik Özellikleri Arasındaki İlişkiler. KSÜ Doğa Bilimleri Dergisi, Özel Sayı, 70-79.

Schroeder HW 1982. Preferred Features of Urban Parks and Forests. Journal of Arboriculture, 8 (12): 317322.

Tips WEJ, Savasdidara T 1986. The Influence of Environmental Background of Subjects on Their Landscape Preference Evaluation. Landscape and Urban Planning, 13:125-133.

Tüfekçioğlu Kuğu H 2008. Tarihsel Çevrede Görsel Peyzaj Kalite Değerlendirmesi İstanbul Yedikule Örneği. İstanbul Teknik Üniversitesi Fen Bilimleri Enstitüsü Peyzaj Mimarlığı Anabilim Dalı, Yüksek Lisans Tezi, İstanbul, $136 \mathrm{~s}$.

Uzun O, Müderrisoğlu H 2011. Visual Landscape Quality in Landscape Planning: Examples of Kars and Ardahan Cities in Turkey. African Journal of Agricultural Research, 6(6): 1627-1638.

Yılmaz H, Özhancı E, Tekin H 2013. Ödüllü Peyzaj Fotoğraflarına Analitik Bir Yaklaşım. Humanitas Uluslararası Sosyal Bilimler Dergisi, 2: 151-168. 